\title{
BID'AH HASANAH TRANSAKSI EKONOMI ISLAM (TERMINOLOGI BID'AH ULAMA)
}

\author{
Nurhadi \\ Sekolah Tinggi Agama Islam (STAI) Al-Azhar Pekanbaru \\ Jl. KH. Ahmad Dahlan No. 96. Suka Jadi, Pekanbaru \\ Riau, Email: alhadicentre@yahoo.co.id
}

\begin{abstract}
The basic rule in the study of fiqih muamalah is al-ashlu fil mu'amalah al-ibahah, illa ma dalla dalilun 'ala tahrimihi, meaning the law of origin of deeds in muamalah is okay, unless there is a proposition that forbid it. The use of the term Islamic Economics is part of the religious heresy, which emerged in the 1940s in the State of India. Thus in the opinion of the Eastern Kuran, Professor of Political Economy, he argues in accordance with the results of his research, proving that Islamic Economics can not be found in Islamic tradition. So the terms and institutions of business now that there is no example of the Prophet and not necessarily present in the time of the prophet are heresy. Well, then what is meant by heresy according to the scholars and is there bid'ah-bid'ah in Islamic economy. The result of the discussion states that heresy is any act that does not exist and is not done at the time of the Prophet which contradicts the texts of the Qur'an and sunna and mashlahah. Seeing modern economic practice, then many bid'ah-bid'ah in Islamic economics, among them is the term Islamic economics itself. The activities of Islamic economics in Indonesia which are bid'ah are syariah banking, zakat propesi and others. Etymologically all three are called heresy, but in terminology can not be said bid'ah. While the rule of fiqih explains "al-ashlu fil mu'amalah al-ibahah, illa ma dalla dalilun 'ala tahrimihi", this is the kaedah closing the meaning of bad connotation of the expression bid'ah, a bid'ah hasanah (good) because it contains many kemashlahatan for humans.
\end{abstract}

Keywords: Bid'ah Hasanah, Transaction Economy Islam

\section{PENDAHULUAN}

Islam agama yang sempurna, mengatur seluruh aspek kehidupan manusia secara detail (syamil mutakamil). Sehingga tidak satu pun sendi kehidupan manusia yang terlepas dari ketentuan syariat Islam. Termasuk dalam hal ekonomi, yang dalam khazanah keilmuan Islam merupakan salah satu kajian dalam fiqih Islam, tepatnya fiqih muamalah. Leteratur fiqih Islam, kajian fiqih secara umum terbagi dalam dua kategori, yaitu fiqih ibadah dan fiqih muamalah. Singkatya dapat dikatakan bahwa fiqih ibadah, kajian fiqih yang mengkaji hal-hal yang mencakup hubungan manusia dengan penciptanya (hablun minallah), misalnya shalat, puasa, zakat dan haji. Adapun fiqih muamalah (hunbungan manusia dengan sesamanya), yang disebut dengan hablun minan al-Nas, misalnya muamalah al-Ahwal al-Syakshiyah (muamalah hukum keluarga, meliputi: nikah, cerai, hak kewajiban suami istri dan oaring tua anak serta waris mewarisi, dan lainya), Iqtishadiyah (muamalah ekonomi, meliputi: jual beli, sewa, pinjaman, hutang, gadai, kerja sama, dan lainya), Qadhaiyah (muamalah peradilan, meliputi: hakim, peradilan, penggugat, tergugat, pidana, perdata dan lainya) dan Siasyah (muamalah politik Islam, meliputi: partai, kepemimpinan, rakyat, wakil rakyat, parlemen, eksekutif dan lainya). Kedua klasifikasi kajian fiqih tersebut memiliki kaidah dasar yang berbeda-beda sesuai dengan kemashlahatanya (maqashid syariah).

Standar kaidah dasar dalam kajian fiqih ibadah adalah al-ashlu fil íbadah attahrim, illa ma dalla dalilun 'alal amri 
bihi, maksusnya asal dalam suatu ibadah itu haram, kecuali ada dalil yang menyuruhnya. Dengan kaidah ini, maka semua bentuk ibadah dalam Islam (ibadah mahdhah) yaitu ibadah yang sudah ditentukan syarat dan ketentuannya seperti misalnya shalat (lima waktu) yang tidak berdasar dalil nash adalah dilarang atau haram. Dalam istilah fiqih, ibadah yang tidak ada dalil sama sekali, baik dalil umum atau khusus yang mensyariatkan ibadah tersebut, maka disebut sebagai ibadah bid'ah.

Sedangkan kaidah dasar dalam kajian fiqih muamalah adalah al-ashlu fil mu'amalah ibahah, illa ma dalla dalilun 'ala tahrimihi, maksudnya hukum asal perbuatan dalam muamalah adalah boleh, kecuali ada dalil yang mengharamkannya. Di antara bentuk muamalah adalah aktivitas-aktivitas ekonomi, seperti jual beli, hutang piutang, sewa, dan transaksi-transaksi lainnya. Bentuk muamalah yang lain adalah hal-hal yang menyangkut politik, sosial, budaya, dan sejenisnya.

Bertolak pada kaidah muamalah di atas, maka sesungguhnya setiap muslim diberi kebebasan untuk melakukan aktivitas-aktivitas ekonomi. Melakukan aktivitas jual beli di pasar, bekerja di kantor, berinvestasi di pasar saham, dan aktivitas-aktivitas ekonomi lainnya adalah mubah atau boleh, selama tidak merupakan bentuk aktivitas yang dilarang atau tidak mengandung unsurunsur yang dilarang. Dalam kajian Ekonomi Islam, hal-hal yang dilarang dalam transaksi ekonomi biasa disingkat dengan istilah MAGHRIB, yang merupakan singkatan dari maisir, gharar, riba, dan bathil. Hal ini juga sering terjadi pada kasus pasar syariah (Idel Waldelmi, 2018), juga dalam masalah zakat (E.A Pailis, 2016) serta dalam pengelolaan sumber keuangan islam. (Mardan, J. A., 2015).
Istilah Ekonomi Islam adalah bagian dari bid'ah agama, yang muncul pada tahun 1940-an di Negara India. Demikan menurut pendapat Timur Kuran, Profesor Ekonomi Politik, ia berpendapat sesuai dengan hasil penelitinya, membuktikan bahwa Ekonomi Islam sama sekali tidak dapat ditemukan dalam tradisi Islam. Hanya saja dalam dua sampai tiga dekade terakhir ini, jumlah uang yang signifikan dan tumbuh cepat telah memasuki industri keuangan yang dikelola sesuai dengan syariat. Menurut sebuah studi, pada akhir tahun 2005, lebih dari 300 lembaga di lebih dari 65 yurisdiksi mengelola aset bernilai sekitar US \$ 700 miliar, meningkat menjadi US \$ 1 triliun dengan cara sesuai syariah. Menyerbarnya ke Negara muslim, Ekonomi Islam semakin membesar dengan berkembangnya portofolio karena para eksportir minyak dan berlipatnya pengalihan instrumen keuangan Islam (seperti hipotik bebas bunga dan surat utang sukuk). (AmalMadinah, 2018)

Sederhana saja, agar pembaca tidak salah paham dalam memahami asal muasal istilah ekonomi Islam, maka penulis mengajak agar merujuk pada tulisan Prof Timur Kuran, guru besar ekonomi dan ilmu politik kelahiran Turki, di Duke University. Ia menulis sebuah buku berjudul Islam and Mammon, ditulis dengan dukungan dari Pemerintah Saudi, Raja Faisal, sebagai Profesor Pemikiran Islam dan Kebudayaan di University of Southern California. Sekarang mengajar di Duke University, Kuran menemukan bahwa ekonomi Islam tidak berasal dari ajaran Nabi Muhammad saw, tetapi merupakan tradisi yang diciptakan atau dibuat-buat (bid'ah) yang muncul pada tahun 1940-an di Negara India. Gagasan tentang disiplin ekonomi yang berbeda dan jelas Islami ini sangatlah baru (muhdast). Bahkan seorang Muslim paling terpelajar seabad yang lalu akan tercengang dengan istilah ekonomi Islam. 


\section{Jurnal Ilmiah Ekonomi dan Bisnis}

Vol. 15. No. 2, September 2018: 122-138

EISSN : $2442-9813$

ISSN : 1829-9822

Gagasan dan Ide melahirkan istilah ekonomi Islam ini berasal dari seorang aktivis Islam, Abul-Ala Maududi (19031979 M), yang menyatakan bahwa ekonomi Islam merupakan suatu disiplin ilmu sebagai bentuk mekanisme dalam mencapai tujuan-tujuan (maqashid syariah): untuk meminimalkan hubungan dengan non-Muslim, memperkuat rasa identitas kolektif Muslim, memperluas jangkauan Islam ke daerah aktivitas baru manusia, dan modernisasi tanpa Westernisasi dalam sebagal transaki binis muamalah Islam.

Setelah resmi sebagai disiplin akademis, ilmu ekonomi Islam semangkin menggeliat dan bergulir sampai pertengahan tahun 1960-an, memperoleh bobot kelembagaannya sebagai lembaga keilmuan ekonomi dari tahun tersebut sampai selama era booming minyak pada tahun 1970-an, yaitu ditandai semenjak Arab Saudi dan eksportir Muslim lainnya, untuk yang pertama kalinya memiliki sejumlah besar uang atau dana kekayaan, yang menjadikannya sumber bantuan besar bagi proyek perminyakan tersebut. Terkhusus di Indonesia, ungkapan atau istilah ekonomi Islam diperhalus menjadi ekonomi syariah berkembang sejak awal 1990-an, ketika Orde Baru mulai ramah terhadap Islam, terbukti lahirnya bank tanpa riba pertama yaitu bank muamalat Indonesia pada tahun 1991 serta beroperasi tahun 1992. (AmalMadinah, 2018)

Para pendukung ekonomi Islam ketika itu membuat dua klaim besar: bahwa system ekonomi kapitalis telah gagal dan bahwa Islam menawarkan obatnya dengan system ekonomi Islam. Dalam mengapresiasi pernyataan terakhir, maka Prof. Kuran memberikan perhatian yang kuat untuk memahami fungsi yang sebenarnya dari ekonomi Islam, dengan fokus pada tiga tuntutan utama, yaitu bahwa ekonomi Islam telah berhasil menghapuskan bunga atas uang (riba), mencapai kesetaraan ekonomi, dan membangun etika bisnis yang superior dan adil.

Menurut Kuran, sampai saat ini belum satu tempat pun praktek ekonomi Islam yang berhasil membersihan secara total bunga riba dari transaksi ekonomi, dan belum satu tempat pun Islamisasi ekonomi mendapatkan dukungan massa yang signifikan. Teknik-teknik eksotis dan rumit dalam pembagian laba-rugi seperti ijarah, mudharabah, murabahah, dan musyarakah semua melibatkan pembayaran bunga secara terselubung. Bank yang mengaku Islam sebenarnya tak lebih dari sekedar lembaga keuangan modern ketimbang sesuatu yang berasal dari warisan Islam, namun itu masih jauh lebih baik dari pada lembaga keuangan konvensional. Singkatnya, masih cukup sedikit nilai Islam dalam perbankan Islam, namun lebih banyak mashlahah, karena dibutuhkan masyarakat. Minimalnya nilai Islam dalam perbankan mislanya masih bertransaksinya bank Islam dengan bank konvensional secara signifikan, dan masih adanya pendapatan non halal dalam bank Islam, kendatipun ini diperdebatkan hukum Islamnya oleh kalangan ulama kontemporer, sebagian mereka berpendapat ini adalah bid'ah sesat ekomomi Islam.

Secara kelembagaan perbankan masih sangat sedikit keberhasilannya dalam menyampaikan tujuan mengurangi kesenjangan dengan pengenaan zakat dalam perbankan, baik dana yang ada maupun organisasi perbankan tersebut (zakat propesi). Lembaga-lembaga perbankan masih sedikit menyerap zakat dari nasabahnya dan pengelolaanya belum sepenuhnya dapat dirasakan oleh pakir miskin, padahal perbankan berfungsi sebagai lembaga intermediasi termasuk zakat, yaitu intermediasi antara si kaya dengan si miskin. Dari latar belakang diatas, maka bagaiamana sebenarnya konsep bid'ah menurut para ulama dan 
adakah bid'ah-bid'ah dalam ekonomi Islam.

\section{METODE}

Dalam melakukan kajian ini, penulis menggunakan dua metodologi yaitu: Kajian Kepustakaan, Kajian kepustakaan tersebut meliputi pencarian data dengan analisis data kualitatif dan kuantitatif. Melalui buku-buku ulama Islam, sama ada ulama Islam yang hidup pada zaman dahulu mahupun sekarang. Ianya juga meliputi data melalui jurnal, makalah, tesis.

\section{PEMBAHASAN}

\section{Konsep Bid'ah Menurut Para Ulama Mazhab}

Menurut Nurhadi (2013) untuk mengkaji masalah ini dianggap perlu mengemukakan konsep Nabi tentang bid'ah dalam hadisnya, misalnya:

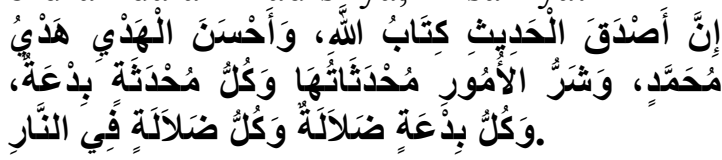

Artinya: "Sesungguhnya ucapan yang paling benar adalah kitab Allah, dan sebaik-baik petunjuk adalah petunjuk Muhammad saw, dan seburuk-buruk perkara adalah perkara baru, setiap perkara baru adalah bid'ah, dan setiap bid'ah itu sesat dan setiap kesesatan itu tempatnya di neraka". (HR. Nasa'i. 2013)

Hadits ini merupakan salah satu dari sekian banyak hadits yang berbicara tentang bid'ah. Namun untuk memahami perkara bid'ah ini tidak asal begitu saja kita pahami secara harfiah atau tekstual dari hadits tersebut, sehingga siapapun menjadi mudah untuk mengklaim saudara-saudaranya semuslim yang melakukan satu perkara yang tidak pernah dilakukan di zaman Nabi saw kita anggap sebagai pelaku bid'ah yang sesat, dan jika ia sesat berarti tempatnya di neraka. Agar tidak berkesan tergesagesa ada baiknya kita memahami terlebih dahulu masalah ini melalui kajian-kajian dari para ulama salafushshalih kita yang telah terebih dahalu mengkajinya.

\section{Mazhab Hanafi}

Al-Imam Badruddin Mahmud bin Ahmad al-'Aini, al-hafizh dan faqih bermadzhab Hanafi membagi bid'ah menjadi dua bagian. Beliau mengatakan: "Bid'ah pada mulanya adalah mengerjakan sesuatu yang belum pernah ada pada masa Rasulullah. Kemudian bid'ah itu ada dua macam. Apabila masuk dalam naungan sesuatu yang dianggap baik oleh syara', maka disebut bid'ah hasanah. Dan apabila masuk di bawah naungan sesuatu yang dianggap buruk oleh syara', maka disebut bid'ah tercela" (HR. Bukhari)

Selain dari Imam al-Aini dari Madzhab Hanafi juga, seperti Syekh Abu Bakar al-Mulla al-Hanafi (2012), Imam al-Kirmani dalam kitabnya, imam Ibnu Abidin dalam kitabnya, Imam atTurkumani dalam kitabnya, dan Imam atTahanawi (2003)

\section{Mazhab Maliki}

Ahmad bin Muhammad AshShawiy al-Maliki. Pada ayat di atas (alHadid 27), Allah Ta'ala memberikan pahala kepada orang-orang beriman diantara mereka, yakni orang-orang yang melakukan bid'ah dengan melakukan rahbaniyah dan memeliharanya dengan semestinya. Arti surah al-Hadid 27: "Kemudian kami iringi di belakang mereka dengan rasul-rasul kami dan kami iringi (pula) dengan Isa putra Maryam; dan kami berikan kepadanya Injil dan kami jadikan dalam hati orang- orang yang mengikutinya rasa santun dan kasih sayang. dan mereka mengada-adakan rahbaniyyah padahal kami tidak mewajibkannya kepada mereka tetapi (mereka sendirilah yang mengadaadakannya) untuk mencari keridhaan Allah, lalu mereka tidak memeliharanya 
Jurnal Ilmiah Ekonomi dan Bisnís

Vol. 15. No. 2, September 2018: 122-138

EISSN : $2442-9813$

ISSN : $1829-9822$

dengan pemeliharaan yang semestinya.

Maka kami berikan kepada orang-orang yang beriman di antara mereka pahalanya dan banyak di antara mereka orang-orang fasik". Beliau menafsirkan surah al-hadid ayat $27 \mathrm{di}$ atas, maka beliau berkata pada ayat tersebut Allah memberikan pahala kepada orang-orang beriman diantara mereka, yakni orangorang yang melakukan bid'ah dengan melakukan rahbaniyah dan memeliharanya dengan semestinya.

Imam Ibnu al-Arabi al-Hafidh alImam Ibnu al-Arabi al-Maliki "Ketahuilah bahwa Bid'ah (almuhdatsah) itu ada dua macam: Pertama, setiap perkara baru yang diadakan yang tidak memiliki landasan agama, melainkan mengikut hawa nafsu sesuka hati, ini adalah Bid'ah yang sesat. Kedua, perkara baru yang diadakan namun sejalan dengan apa yang sudah disepakati, seperti yang dilakukan oleh para Khulafa'urrasyidin dan para Imam besar, maka hal tersebut bukanlah bid'ah yang keji dan tercela. Ketahuilah, sesuatu itu tidak dihukumi bid'ah hanya karena ia baru.

Al-Imam Abu Umar Yusuf bin Abdil barr al-Namiri al-Andalusi bermadzhab Maliki (1993). Beliau membagi bid'ah menjadi dua. Hal ini dapat kita lihat dengan memperhatikan pernyataan beliau: "Adapun perkataan Umar, sebaik-baik bid'ah, maka bid'ah dalam bahasa Arab adalah menciptakan dan memulai sesuatu yang belum pernah ada. Maka apabila bid'ah tersebut dalam agama menyalahi sunnah yang telah berlaku, maka itu bid'ah yang tidak baik, wajib mencela dan melarangnya, menyuruh menjauhinya dan meninggalkan pelakunya apabila telah jelas keburukan alirannya. Sedangkan bid'ah yang tidak menyalahi dasar syariat dan sunnah, maka itu sebaik-baik bid'ah."

Abu Abdillah Muhammad bin Ahmad bin Abu Bakr bin Farh al-
Anshari al-Khazraji al-Andalusi alQurthubi atau Imam Qurthubi bermazhab Maliki, "Menanggapi ucapan ini (ucapan Imam Syafi'i), maka kukatakan (Imam Qurtubi berkata) bahwa makna hadits Nabi saw yang berbunyi :

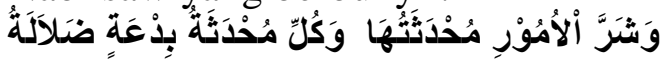

Artinya: "Seburuk-buruk permasalahan adalah hal yang baru, dan semua Bid'ah adalah dhalalah"

Yang dimaksud adalah hal-hal yang tidak sejalan dengan al-Qur'an dan Sunnah Rasul, atau perbuatan Sahabat, sungguh telah diperjelas mengenai hal ini oleh hadits lainnya :

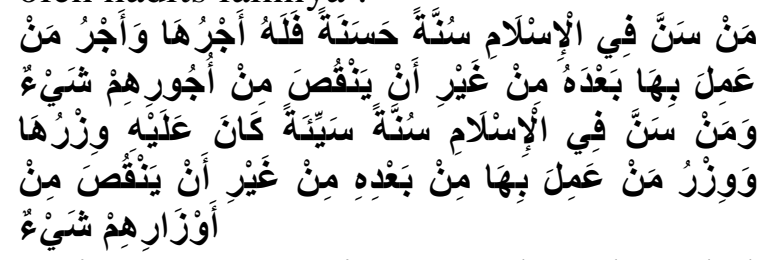

Artinya: "Barangsiapa membuat buat hal baru yg baik dalam islam, maka baginya pahalanya dan pahala orang yg mengikutinya dan tak berkurang sedikitpun dari pahalanya, dan barangsiapa membuat buat hal baru yg buruk dalam islam, maka baginya dosanya dan dosa orang yg mengikutinya"

Hadits diatas merupakan inti penjelasan mengenai bid'ah yang baik dan bid'ah yg sesat".

Dan diantara ulama lain dari Madzhab Maliki seperti, al-Qarafi (2001) dan az-Zarqani at-Turtusyi, Ibnul-Hajj, silahkan lihat di kitab-kitab mereka.

Selain para ulama diatas yang bermazhab Maliki, maka Imam Syathibi, beliau mendefinisikan bahwa "Bid'ah adalah suatu cara yang diada-adakan dalam agama, yang bentuknya menyerupai syari'at, dan yang dimaksud dari penerapannya adalah untuk berlebihlebihan dalam beribadah kepada Allah. (Abu Ishak, 1997) Pendapat asy-Syathibi inilah yang kemudian diangkat oleh Rasyid Ridha, Salim Hilali dan Muhammad Abdussalam Khadir asySyuqairi (murid Rasyid Ridha). 


\section{Mazhab Syafi'i}

Imam Syafi'i (Syaikhul Akbar Mutjahid Mutlaq Nashirussunah alHakim al-Imam Asy Syafi'i, 1997) "Bid'ah terbagi menjadi 2 bagian: Perkara baru yang menyalahi al-Qur'an, Sunnah, Ijma' atau menyalahi Atsar (sesuatu yang dilakukan atau dikatakan sahabat tanpa ada di antara mereka yang mengingkarinya), perkara baru semacam ini adalah bid'ah yang sesat. Sedangkan jika tidak menyalahinya, maka sesuatu yang baru seperti ini tidak tercela".

Imam Nawawi al-Imam alMuhaddits al-Hafizh Abu Zakariya Yahya bin Syaraf An-nawawi, Pakar Hadits Besar, Rijalussanad Imam Syafi'i. "Bid'ah menurut syari'at adalah segala sesuatu yang tidak pernah ada pada zaman Rasulullah Saw. Bid'ah terbagi menjadi dua, baik dan buruk." Beliau melanjutkan: "Para pemuka umat dan Imam kaum muslimin yang ilmunya sudah diakui, seperti Abu Muhammad Abdul Aziz bin Abdissalam menyebut di akhir buku beliau, al-Qawa`id (alKubra) bid'ah terbagi lima macam (bid'ah wajib, haram, sunah, makruh dan mubah). Selebihnya adalah bid'ah yang boleh." Beliau mengatakan:

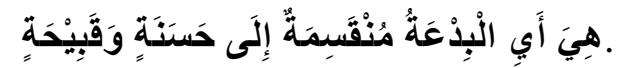

Artinya: "Bid'ah terbagi menjadi dua, bid'ah hasanah (baik) dan bid'ah qabihah (buruk)",

Sedangkan hadist yang menyebutkan setiap bid'ah adalah sesat, ini sudah ada pengkhususan (takhshish), yaitu yang bertentangan dengan syariat, hadist umum ini diakui juga oleh Imam al-Nawawi dan lainnya.

Imam Ibnu Hajar al-Asqalani alHujjatul Islam Amirul Mukminin fiil Hadits, hafizh dan faqih bermadzhab Syafi'I (2003). Beliau membagi bid'ah menjadi dua, bahkan menjadi lima bagian. Dalam kitabnya Fath al-Bari, ia mengatakan: "Secara bahasa, bid'ah adalah sesuatu yang dikerjakan tanpa mengikuti contoh sebelumnya. Dalam syara', bid'ah diucapkan sebagai lawan sunnah, sehingga bid'ah itu pasti tercela. Sebenarnya, apabila bid'ah itu masuk dalam naungan sesuatu yang dianggap baik menurut syara', maka disebut bid'ah hasanah. Bila masuk dalam naungan sesuatu yang dianggap buruk menurut syara', maka disebut bid'ah mustaqbahah (tercela). Dan bila tidak masuk dalam naungan keduanya, maka menjadi bagian mubah (boleh). Dan bid'ah itu dapat dibagi menjadi lima hukum."

Al-Hujjatul Islam al-Imam Ghazali (2007) "Hakikat bahwa ia adalah perkara baru yang diadakan tidaklah menghalanginya untuk dilakukan. Banyak sekali perkara baru yang terpuji, seperti sembahyang Terawih secara berjama'ah, ia adalah "Bid'ah" yang dilakukan oleh Sayyidina'Umar, tetapi dipandang sebagai Bid'ah yang baik (Bid'ah Hasanah). Adapun Bid'ah yang dilarang dan tercela, ialah segala hal baru yang bertentangan dengan Sunnah Rasulullah Saw atau yang bisa merubah Sunnah itu.

Al-Imam Izzuddin bin Abdissalam (2001) membagi bid'ah menjadi lima bagian. Dalam pandangan beliau bid'ah itu terbagi menjadi lima bagian; bid'ah wajibah, bid'ah mandubah (sunnat), bid'ah mubahah, bid'ah makruhah dan bid'ah muharramah (haram). Bid'ah wajibah memiliki banyak contoh. Salah satunya adalah menekuni ilmu nahwu sebagai sarana memahami Al-Quran dan Sunnah Rasulullah. Hal ini hukumnya wajib, karena menjaga syariat itu wajib dan tidak mungkin dapat menjaganya tanpa mengetahui ilmu nahwu. Sedangkan sesuatu yang menjadi sebab terlaksananya perkara wajib, maka hukumnya wajib. Kedua, berbicara dalam jarh dan ta'dil untuk membedakan hadits yang shahih dan yang lemah. Bid'ah muharramah memiliki banyak contoh, di antaranya bid'ah ajaran orang-orang Qadariyah, Jabariyah, Murji'ah dan Mujassimah. 
Jurnal Ilmiah Ekonomi dan Bisnís

Vol. 15. No. 2, September 2018: 122-138

EISSN : $2442-9813$

ISSN : $1829-9822$

Sedangkan menolak terhadap bid'ahbid'ah tersebut termasuk hukumnya wajib. Bid'ah mandubah memiliki banyak contoh, di antaranya mendirikan sekolah-sekolah dan setiap kebaikan yang pernah dikenal pada abad pertama, dan di antaranya shalat tarawih. Bid'ah makruhah memiliki banyak contoh, di antaranya memperindah bangunan masjid dan menghiasi mushhaf AlQuran. Bid'ah mubahah memiliki banyak contoh, di antaranya menjamah makanan dan minuman yang lezat-lezat, pakaian yang indah, tempat tinggal yang mewah, memakai baju kebesaran dan lain-lain".

Imam Ibnu Hajar al-Haitamiy alHujjatul Islam al-Muhaddits al-Imam Ibnu Hajar al-Haitami "Adapun yang tidak bertentangan dengan agama, yakni yang didukung oleh dalil syara' atau qawaid syara' maka tidak tertolak pelakunya, bahkan amalannya diterima" beliau melanjutkan, Hadits riwayat Aisyah, Rasulullah Saw bersabda "Barang siapa yang mengada-adakan sesuatu (amalan) dalam urusan (agama) kami yang bukan dari agama kami, maka (amalan) itu tertolak".

Ibnu Hajar al-Haitamy (2003) mengatakan bahwa makna "maa laisa minhu" (sesuatu yang bukan dari agama kami) adalah sesuatu yang bertentangan dengan agama atau tidak didukung oleh qawaid agama atau dalil-dalil agama yang bersifat umum. Dalam uraian beliau selanjutnya, beliau berkata : "Adapun yang tidak bertentangan dengan agama, yakni yang didukung oleh dalil syara' atau qawaid syara' maka tidak tertolak pelakunya, bahkan amalannya diterima".

Al-Muhaddis al-Hujjatul Islam al-Imam Jalaluddin as-Suyuthi mengenai hadits "Bid'ah Dhalalah" ini bermakna "Aammun makhsush", (sesuatu yg umum yg ada pengecualiannya), seperti firman Allah : “... yang menghancurkan segala sesuatu", dan kenyataannya tidak segalanya hancur, atau ayat : "Sungguh telah kupastikan ketentuanku untuk memenuhi jahannam dengan jin dan manusia keseluruhannya", dan pada kenyataannya bukan semua manusia masuk neraka, tapi ayat itu bukan bermakna keseluruhan tapi bermakna seluruh musyrikin dan orang dhalim) atau hadits : "aku dan hari kiamat bagaikan kedua jari ini" (dan kenyataannya kiamat masih ribuan tahun setelah wafatnya Rasul saw).

Muhammad bin Abdur Ra'uf alMunawi atau al-Imam al-Munawi (1982), beliau berpendapat adapun yang ada azhidnya yakni didukung oleh dalil atau qaidah syara', maka tidak tertolak bahkan amalannya diterima misalnya membangun seperti organisasi dan madrasah, mengarang ilmu pengetahuan dan lainlain."

Al-Imam al-Hafizh Ibn al-Atsir alJazari, pakar hadits dan bahasa, juga membagi bid'ah menjadi dua bagian; bid'ah hasanah (baik) dan bid'ah sayyi'ah (buruk). Dalam kitabnya, al-Nihayah fi Gharib al-Hadits wa al-Atsar, beliau mengatakan: "Bid'ah ada dua macam; bid'ah huda (sesuai petunjuk agama) dan bid'ah dhalal (sesat). Maka bid'ah yang menyalahi perintah Allah dan Rasulullah, tergolong bid'ah tercela dan ditolak. Dan bid'ah yang berada di bawah naungan keumuman perintah Allah dan dorongan Allah dan Rasul-Nya, maka tergolong bid'ah terpuji. Sedangkan bid'ah yang belum pernah memiliki kesamaan seperti semacam kedermawanan dan berbuat kebajikan, maka tergolong perbuatan yang terpuji dan tidak mungkin hal tersebut menyalahi syara'."

Syaikh Wahbah Azzuhaili (Pakar Ushul Fiqih) "Setiap bid'ah yang terjadi dari makhluk, tidak terlepas dari dalil, adakala ada dalilnya pada syara' atau tidak ada dalilnya. Jika ada dalil pada syara', maka ia termasuk dalam umum yang dianjurkan Allah dan Rasul kepadanya. Oleh karena itu, ia termasuk 
dalam katagori terpuji, meskipun yang sama dengannya tidak pernah ada sebelumnya seperti yang termasuk dalam katagori kebaikan, dermawan dan perbuatan ma'ruf. Maka semua perbuatan ini termasuk perbuatan terpuji, meskipun tidak ada yang melakukannya sebelumnya. Didukung ini oleh perkataan Umar "sebaik-baik bid'ah adalah ini" dengan sebab ini termasuk dalam katagori perbuatan baik dan katagori terpuji. Dan jika ia masuk dalam katagori menyalahi apa yang diperintah Allah dan Rasul, maka ia termasuk dalam katagori tercela dan ingkar".

\section{Mazhab Hambali}

Ibnu Rajab Al-Hambali (2008) bahwa semua perbuatan yang diberi pahala dan disyariatkan melakukannya tidak dinamakan bid'ah, sekalipun hal itu pantas dinamakan bid'ah dari segi bahasa, yaitu perbuatan baru yang belum pernah ada yang melakukannya, akan tetapi penamaan bid'ah terhadap perbuatan ini tidak dimaksudkan sebagai bid'ah yang tercela apalagi sesat.

Pendapat ini diikuti oleh Imam al-Syamani dan al-Ainy (mazhab Hanafi), al-Baihaqi, Ibnu Hajar alAsqalani, dan Ibnu Hajar al-Haitsami (mazhab Syafi'i), dan Madzhab Hambali, Ibnu Qayyim al- Jauziyah dan Ibnu Taimiyah (mazhab Hanbali). Mereka menggunakan definisi bid'ah yang ditulis oleh Imam al-Syatibi. Pendapat ini tidak mengakui penamaan bid'ah hasanah (baik). Namun, Syaikh Abdul Lathif al-Sha'idi mengatakan, Imam al-Syathibi (2006) mengakui adanya bid'ah hasanah, tapi dia menyebutnya dengan istilah Mashlahah Mursalah.

Namun begitu, Syaikh Abdullah bin Baz pengikut pendapat kedua ini mengatakan, bahwa larangan melakukan bid'ah itu hanya pada masalah ibadah saja, dan tidak berlaku pada masalah muamalah (jual beli) dan adat teradisi. Karena muamalah yang bertentangan dengan syariat Islam disebut dengan batil, bukan bid'ah. Dengan konsep ini, Syaikh Ibnu Utsaimin menegaskan, bid'ah ialah beribadah kepada Allah Swt dengan melakukan ritual yang tidak disyariatkan oleh Allah Swt, Rasulullah Saw, dan Khulafa al-Rasyidin.

\section{Bid'ah-Bid'ah Dalam Ekonomi Islam}

Seorang Propesor dalam ilmu ekonomi politik, bernama Timur Kuran, menyatakan bahwa penggunaan istilah Ekonomi Islam adalah bagian dari bid'ah agama dalam ekonomi (muamalah iqtishadiyah). Maka menurut penulis diantara bid'ah-bid'ah dalam ekonomi Islam di Indonesia adalah:

\section{Bank Syariah}

Berkaca pada pendapat Timur Kuran, maka menurut penulis bank syariah adalah bagian dari bid'ah-bid'ah dalam kajian fiqih muamalah. Secara historis perbankan syariah tidak ada pada masa Nabi saw. Kendatipun demikian, para penggagas dan penyanjung ekonomi Islam, menyatakan bahwa bank pada zaman Nabi saw sudah ada, mereka menyamakanya dengan bait al-Maal (rumah harta), yang fungsinya secara tidak langsung hampir sama dengan perbankan di zaman sekarang, yaitu mengumpulkan dana, menyalurkanya dan jasa lainya.

\section{Perbankan pada masa Nabi saw dan Sahabat}

Sejarah perekonomian kaum muslimin, pembiayaan yang dilakukan dengan akad yang sesuai syariah telah menjadi bagian dari tradisi umat Islam sejak zaman Rasulullah saw. Praktikpraktik seperti menerima titipan harta, meminjamkan uang untuk keperluan konsumsi dan untuk keperluan bisnis, serta melakukan pengiriman uang, telah lazim dilakukan sejak zaman Rasulullah 
Jurnal Ilmiah Ekonomi dan Bisnis

Vol. 15. No. 2, September 2018: 122-138

EISSN : $2442-9813$

ISSN : $1829-9822$

saw (Nurhadi, 2016). Dengan demikian, fungsi-fungsi utama perbankan modern yaitu menerima deposit, menyalurkan dana, dan melakukan transfer, telah menjadi bagian yang tidak terpisahkan dari kehidupan umat Islam, bahkan sejak zaman Rasulullah saw. Rasulullah saw yang dikenal dengan julukan al-Amin, dipercaya oleh masyarakat Mekah menerima simpaanan harta, sehingga pada saat terakhir sebelum Rasul saw hijrah ke Madinah, beliau meminta Sayidina Ali r.a untuk mengembalikan semua titipan itu kepada yang memilikinya. (Nurulistiana, 2018)

Dalam konsep ini, yang di titipi tidak dapat memanfaatkan harta titipan tersebut. Seorang sahabat Rasulullah saw, Zubair bin al-Awwam, memilih tidak menerima titipan harta. Beliau lebih suka menerimanya dalam bentuk pinjaman. Tindakan Zubair ini menimbulkan implikasi yang berbeda, yaitu: 1). Dengan mengambil uang itu sebagai pinjaman, beliau mempunyai hak untuk memanfaatkannya; 2). Karena bentuknya pinjaman, maka ia beliau berkewajiban mengembalikannya utuh.

Sahabat lain, Ibnu Abbas tercatat melakukan pengiriman uang ke Kufah. Juga tercatat Abdullahbin Zubair yang tinggal di Irak. Penggunaan cek juga sudah di kenal luas sejalan dengan meningkatnya perdagangan negara Syam dengan Yaman, paling tidak terjadi dan berlangsung dua kali dalam setahun. Bahkan di zaman Umarbin Khattab, beliau menggunakan cek untuk membayar tunjangan kepada mereka yang berhak. Dengan cek ini mereka kemudian mengambil gandum di Baitul Mal yang ketika itu di impor dari Mesir. Pemberian modal untuk modal kerja berbasis bagi hasil, seperti mudharabah, musyarakah, muzara'ah, musaqah, telah dikenal sejak awal diantara kaum Muhajirin dan kaum Anshar. Jelaslah bahwa ada individu-individu yang telahmelaksanakan fungsi perbankan pada masa Rasul saw.

\section{Perbankan pada masa Bani Umayyah dan Abbasiyah}

Pada masa Bani Abbasiyah, ketiga fungsi perbankan dilakukan oleh satu individu. Fungsi-fungsi perbankan yang dilakukan oleh satu individu, dalam sejarah Islam telah dikenal sejak Bani Abbasiyah (2010). Jelas saja institusi bank tidak dikenal dalam kosa kata fikih islam, karena memang institusi ini tidak dikenal oleh masyarakat Islampada zaman Rasulullah saw, Khulafur Rasyidin, Bani Umayyah, maupun Bani Abbasiyah (2018). Namun fungsi-fungsi perbankan yaitu menerima deposit, menyalurkan dana, dan transfer dana telah lazim dilakukan, tentunya yang sesuai dengan akad yang sesuai syariah Rasul saw.

Perbankan mulai berkembang pesat ketika beredar banyak jenis mata uang pada zaman itu sehingga perlu keahlian khusus untuk membedakan satu mata uang dengan mata uang yang lain. Ini diperlukan karena setiap mata uang mempunyai kandungan logam mulia yang berlainan sehingga mempunyai nilai yang berbeda pula. Orang yang memiliki keahlian khusus ini disebut naqid, sarraf, dan jihbiz (2018). Hal ini merupakan cikal-bakal praktek penukaran mata uang (money changer). Istilah jihbiz mulai dikenal sejak zaman Muawiyah (661$680 \mathrm{M})$ yang sebenarnya dipinjam dari bahasa Persia, kahba data ukih bud. Pada masa pemerintahan Sasanid, istilah ini dipergunakan untuk orang yang ditugaskan mengumpulkan pajak tanah.

Peranan bank pada zaman Abbasiyah mulai populer pada pemerintahan Muqtadir (908-932M). Saat itu, hampir setiap wazir mempunyai bankir sendiri. Misalnya, Ibnu Furat menunjuk Harun ibnu Imran dan Joseph ibnu wahab sebagai bankirnya. Lalu Ibnu Abi Isa menunjuk Ali ibn Isa, Hamid ibnu Wahab menunjuk Ibrahim ibn Yuhana, bahkan Abdullah al-Baridi 
mempunyai tiga orang bankir sekaligus: dua Yahudi dan satu Kristen.

Kemajuan praktek perbankan pada zaman itu ditandai dengan beredarnya saq (cek) dengan luas sebagai media pembayaran. Bahkan, peranan bankir telah meliputi tiga aspek, yakni menerima deposit, menyalurkannya, dan mentransfer uang. Dalam hal yang terakhir ini, uang dapat ditransfer dari satu negeri ke negeri lainnya tanpa perlu memindahkan fisik uang tersebut. Para money changer yang telah mendirikan kantor-kantor di banyak negeri telah memulai penggunaan cek sebagai media transfer uang dan kegiatan pembayaran lainnya. Dalam sejarah perbankan Islam, adalah Sayf al-Dawlah al-Hamdani yang tercatat sebagai orang pertama yang menerbitkan cek untuk keperluan kliring antara Baghdad (Irak) dan Aleppo (Spanyol sekarang).

\section{Perbankan pada masa Modern}

Pemikiran untuk mendirikan bank yang menggunakan prinsip bagi hasil sudah muncul dalam waktu yang cukup lama. Hal ini di tandai dengan munculnya pemikiran muslim yang menulis tentang perlunya di bangun bank Islam dengan prinsip bagi hasil. Sehingga muncul para pemikir islam yang menulis mengenai bank syariah, mereka di antaranya Anwar Quraeshi (1946), Naiem Siddiq (1948), dan Mahmud Ahmad (1952) dan di tulis kembali secara terperinci oleh Mawdudi (1961). (Abdul Manan (2012).

Perkembangan bank syariah modern tercatat di Pakistan dan Malaysia sekitar tahun 1940, yang pada waktu itu adalah usaha pengelolaan dana jamaah haji secara nonkonvensional. Pada tahun 1940 di Mesir di dirikan Mit Ghamr Lokal Saving Bank (Mit Ghamr bank) (Ahmad, 1972) oleh Prof. Dr. Ahmad El-Najjar yang dibantu oleh Raja Faisal dari Arab Saudi. Bank ini beroprasi tanpa bunga dan sejalan dengan prinsip-prinsip ajaran agama Islam ini sangat populer dan pada mulanya tumbuh dengan baik. Oleh karena itu ada persoalan politik di Mesir lalu bank ini ditutup dan diambil oleh National Bank Of Egypt dan Central Bank Of Egypt yang dioperasikan berdasarkan prinsip ribawi. Pada tahun 1972 sistem bank tanpa riba diperkenalkan lagi di Mesir dengan ditandai berdirinya Nasser Social Bank. Berdirinya bank ini lebih bersifat sosial dari pada komersial. (Salman, 2001)

Kesukaan Mit Ghamr mengelola bank dengan sistem bagi hasil, memberi inspirasi bagi umat islam diseluruh dunia untuk membentuk bank Islam dengan sistem bagi hasil. Secara kolektif gagasan berdirinya bank syariah ditingkat internasional muncul dalam konferensi negara Islam sedunia di Kuala Lumpur, Malaysia pada tanggal 21-27 April 1969 yang diikuti oleh 19 negara peserta. Salah satu keputusan dalam konferensi ini adalah perlu segera dibentuk bank syariah yang bersih dari sistem riba. Kemudian pada Desember 1970 dalam pertemuan menteri negeri negara Organisasi Konferensi Islam (OKI) di Karachi, Pakistan, delegasi mesir mengajukan sebuah proposal untuk mendirikan bank syariah. Proposal tentang berdirinya bank Islam ini kemudian di kaji dengan seksama oleh para ahli dari delapan belas negara Islam yang semuanya menyetujui dibentuk bank Islam.(Adiwarman, 2018) Selanjutnya pada sidang luar negeri negara OKI di Baghazi, Libia pada Maret 1973 usulan tentang perlunya didirikan bank syariah diagendakan lagi. Sehingga pada tahun 1974 diadakan pertemuan menteri keuangan negara OKI di Jeddah dan dalam pertemuan ini disetujui rencana pendirian bank pembangunan Islam (Islamic Development Bank) dengan modal awal dua miliar dinar.

Setelah Islamic Development Bank (IDB) didirikan pada Oktober 
Jurnal Ilmiah Ekonomi dan Bisnis

Vol. 15. No. 2, September 2018: 122-138

EISSN : $2442-9813$

ISSN : $1829-9822$

1970/1975 yang beranggotakan 22 negara Islam sebagai pendiri. Tujuan dibentuk bank ini adalah untuk membantu finansial dalam membangun negara anggotanya, usaha untuk mendirikan bank Islam menyebar kebanyak negara. Beberapa negara seperti Pakistan, Sudan, dan Iran mengubah seluruh sistem keuangan yang ada dinegara tersebut menjadi bebas bunga, sehingga semua lembaga keuangan di negara tersebut beroperasi berdampingan dengan bank-bank konvensional. (Abdullah, 1996)

Sekarang, perbankan syariah sudah mengalami perkembangan yang cukup pesat dan menyebar ke seluruh dunia. Di Eropa tercatat The Islamic Bank Internasional Of Denmark tercatat sebagai bank syariah pertama yang beroperasi berdasarkan prinsip syariah, bank ini mulai beroperasi pada 1983 di Denmark. Sekarang bank-bank besar di negara-negara Eropa seperti City Bank, ANZ Bank, Chase Mahatam Bank, dan Jardine Fleming telah pula membuka Islamic Window agar dapat memberikan jasa-jasa perbankan yang sesuai dengan prinsip-prinsip syariat Islam.

\section{Perbankan Syariah di Indonesia}

Pada tahun 1998 setelah adanya rekomendasi loka karya ulama tentang bunga bank dan perbankan di Cisarua, Bogor pada tanggal 19-22 agustus 1990, hasil lokakarya tersebut dibahas lebih mendalam pada Musyawarah Nasional IV Majelis Ulama Indonesia (MUI) yang berlangsung di Hotel Sahid Jaya, Jakarta pada 22-25 Agustus 1990. Berdasarkan amanat Munas MUI ini dibentuklah keompok kerja untuk mendirikan bank syariah di Indonesia. Hasil kerja dari kelompok ini adalah dibentuknya PT. Bank Muamalah di Indonesia dengan ditandatangani akta pendirinya pada 1 Noveember 1991 dengan total modal awal sebesar Rp. 106.126.382.000,-. Dana ini berasal dari presiden dan wakil presiden, juga dari 10 Menteri Kabinet Pembangunan V, Supersemer, Yayasan Darmais, Yayasan Purna Bakti Pratiw, PT PAL, dan PT Pindad. Pada 1 Mei 1992 Bank Muamalat Indonesiamulai beroprasi.(Akh, 2018)

Pada awal berdirinya, keberadaan PT Bank Muamalat Indonesia belum mendapatkan perhatian yang optimal dalam tatanan industri perbankan nasional. Dimana perbankan bagi hasil diakomodasikan dan diakui keberadaanya, maka perkembngan bank syariah mulai menunjukan prospeknya yang sangat bagus. Dalam menanggapi beberapa pasal yang tersebut dalam Undang-Undang Nomor 7 Tahun 1992, pemerintah mengeluarkan peraturan pemerintah (PP) Nomor 72 Tahun 1992 tenteng bank berdasarkan prisip bagi hasil pada 30 Oktober 1992, LNRI Nomor 119 Tahun 1992. Dalam peraturan pemerintah ini ditegaskan bahwa bank umum atau bank pengkreditan rakyat yang kegiatan usahanya semata-mata berdasarkan prinsip bagi hasil, tidak diperkenankan melakukan usaha yang tidak berdasarkan prinsip bagi hasil, demikian juga sebaliknya.

Dari pemaparan diatas tentang perbankan syariah, maka penulis mencoba memuqarranahkannya secara moderat. Perbankan syariah secara modern sekarang dapat dikatakan sebagai bentuk bid'ah, karena tidak ada pada masa Nabi saw, namun fungsinya sudah ada pada masa itu, maka keberadaan bank syariah sekarang bahagian dari bentuk bid'ah hasanah, karena kaedah fiqih menyatakan: al-ashlu fil mu'amalah ibahah, illa ma dalla dalilun 'ala tahrimihi, maksudnya hukum asal perbuatan dalam muamalah adalah boleh, kecuali ada dalil yang mengharamkannya.

\section{Zakat Propesi}

Diantara bid'ah-bid'ah dalam ekonomi Islam adalah zakat propesi (penghasilan). Zakat profesi dikenal 
dengan istilah zakah rawatib almuwazhaffin (zakat gaji pegawai) atau zakah kasb al-'amal wa al-mihan alhurrah (zakat hasil pekerjaan dan profesi swasta). (Yusuf Al-Qaradhawi) Zakat profesi terdiri dari dua kata yaitu zakat dan profesi. Menurut Wahbah alZuhayly zakat adalah penuanaian hak yang wajib yang terdapat dalam harta. Dalam kamus Bahasa Indonesia, profesi adalah bidang pekerjaan yang dilandasi pendidikan keahlian (keterampilan, kejujuran, dan sebagainya) tertentu. (Agus, 2015) Zakat profesi didefinisikan sebagai zakat yang dikenakan pada tiap pekerjaan atau keahlian profesional tertentu, baik yang dilakukan sendiri maupun bersama orang atau lembaga lain, yang mendatangkan penghasilan (uang) yang memenuhi nishab.(Didin, 2008)

Zakat profesi merupakan perkembangan kontemporer, yaitu disebabkan adanya profesi-profesi modern yang sangat mudah menghasilkan uang. Misalnya profesi dokter, konsultan, advokat, dosen, arsitek, dan sebagainya.(Deni, 2011) Kenyataan membuktikan bahwa pada akhir-akhir ini banyak orang yang karena profesinya, dalam waktu yang relatif singkat, dapat menghasilkan uang yang begitu banyak (Arid, 2006). Kalau persoalan ini dikaitkan dengan pelaksanaan zakat yang berjalan di masyarakat maka terlihat adanya kesenjangan atau ketidakadilan antara petani yang memiliki penghasilan kecil dan mencurahkan tenaga yang banyak dengan para profesional misalnya dokter, akuntan, konsultan, notaris, dan insinyur yang hanya dalam waktu relatif pendek memiliki hasil yang cukup besar tanpa harus mencurahkan tenaga yang banyak (Muhammad, 2012). Adapun pekerjaan atau keahlian profesional tersebut bisa dalam bentuk usaha fisik, seperti pegawai atau buruh, usaha pikiran dan ketrampilan seperti konsultan, insinyur, notaris dan dokter, usaha kedudukan seperti komisi dan tunjangan jabatan, dan usaha lain seperti investasi (Hamrozi, 2007). Hasil usaha profesi juga bisa bervariasi, misalnya hasil yang teratur dan pasti setiap bulan, minggu atau hari seperti upah pekerja dan pegawai atau hasil yang tidak tetap dan tidak dapat diperkirakan secara pasti, seperti kontraktor dan royalti pengarang (Hamidah, 2018).

Ulama' berbeda pendapat mengenai hukum zakat penghasilan atau profesi. Mayoritas ulama madzhab empat tidak mewajibkan zakat penghasilan pada saat menerima kecuali sudah mencapai nishab dan sudah sampai setahun (haul), namun para ulama mutaakhirin seperti Yusuf Al-Qaradhawi (2007) dan Wahbah Az-Zuhaili, menegaskan bahwa zakat penghasilan itu hukumnya wajib pada saat memperolehnya, meskipun belum mencapai satu tahun. Hal ini mengacu pada pendapat sebagian sahabat yaitu Ibnu Abbas, Ibnu Mas'ud dan Mu'awiyah, Tabiin Az-Zuhri, Al-Hasan Al-Bashri, dan Makhul juga pendapat Umar bin Abdul Aziz dan beberapa ulama fiqh lainnya. Adapun kewajiban zakatnya adalah 2,5\%, berdasarkan keumuman nas yang mewajibkan zakat uang, baik sudah mencapai satu haul atau ketika menerimanya. Jika sudah dikeluarkan zakatnya pada saat menerimanya, maka ia tidak wajib mengeluarkan zakat lagi pada akhir tahun. Dengan demikian ada kesamaan antara pegawai yang menerima gaji secara rutin dengan petani yang wajib mengeluarkan zakat pada saat panen, tanpa ada perhitungan haul. Menurut alQaradhawi nishab zakat profesi senilai 85 gram emas dan jumlah zakat yang wajib dikeluarkan adalah 2,5\%. Landasan fikih (at-takyif al-fiqhi) zakat profesi ini menurut Al-Qaradhawi adalah perbuatan sahabat yang mengeluarkan zakat untuk al-maal al-mustafaad (harta perolehan). Al-maal al-mustafaad adalah setiap harta baru yang diperoleh seorang muslim 
Jurnal Ilmiah Ekonomi dan Bisnís

Vol. 15. No. 2, September 2018: 122-138

EISSN : $2442-9813$

ISSN : 1829-9822

melalui salah satu cara kepemilikan yang disyariatkan, seperti waris, hibah, upah pekerjaan, dan yang semisalnya. Al-Qaradhawi mengambil pendapat sebagian sahabat (seperti Ibnu Abbas dan Ibnu Mas'ud) dan sebagian tabi'in (seperti Az-Zuhri, Hasan Bashri, dan Makhul) yang mengeluarkan zakat dari al-maal al-mustafaad pada saat menerimanya, tanpa mensyaratkan haul (dimiliki selama satu tahun qamariyah). Bahkan al-Qaradhawi melemahkan hadis yang mewajibkan haul bagi harta zakat, yaitu hadis Ali bin Abi Thalib RA, bahwa Nabi saw bersabda"Tidak ada zakat pada harta hingga berlalu atasnya haul." (HR Abu Dawud).

Seorang yang mendapatkan penghasilan halal dan mencapai nishab (85 gr emas) wajib mengeluarkan zakat 2,5\%, boleh dikeluarkan setiap bulan atau di akhir tahun. Sebaiknya zakat dikeluarkan dari penghasilan kotor sebelum dikurangi kebutuhan yang lain. Ini lebih afdlal (utama) karena khawatir ada harta yang wajib zakat tapi tidak dizakati, tentu akan mendapatkan adzab Allah baik di dunia dan di akhirat. Juga penjelasan Ibnu Rusd bahwa zakat itu ta'bbudi (pengabdian kepada Allah swt) bukan hanya sekedar hak mustahiq. (Rusyd, 1960) Tapi ada juga sebagian pendapat ulama membolehkan sebelum dikeluarkan zakat dikurangi dahulu biaya oprasional kerja atau kebutuhan pokok sehari-hari.

Menurut penulis sesuai dengan pemaparan tentang zakat propesi diatas, maka memang benar bahwa zakat propesi tidak ada pada Nabi saw, maka ini termasuk bid'ah, namun karena kemashlahatan yang cukup besar dalam rangka mengentaskan kemiskinan sesuai hikmah dari diwajibkanya zakat, maka zakat propesi kategori bid'ah hasanah atau bid'ah yang baik. Hal ini juga berdasar pada ketentuan kaedah fiqih: al-ashlu fil mu'amalah ibahah, illa ma dalla dalilun 'ala tahrimihi, maksudnya hukum asal perbuatan dalam muamalah adalah boleh, kecuali ada dalil yang mengharamkannya. Dalam hal zakat ini penuis lebih cenderung bahwa zakat propesi kategori muamalah walaupun ada juga nilai ibadahnya, namun lebih kuat pada ranah muamalah antara si kaya dan si miskin.

\section{KESIMPULAN}

Kaidah dasar dalam kajian fiqih muamalah adalah al-ashlu fil mu'amalah ibahah, illa ma dalla dalilun 'ala tahrimihi, maksudnya hukum asal perbuatan dalam muamalah adalah boleh, kecuali ada dalil yang mengharamkannya. Penggunaan istilah Ekonomi Islam adalah bagian dari bid'ah agama, yang muncul pada tahun 1940-an di Negara India. Demikan menurut pendapat Timur Kuran, Profesor Ekonomi Politik, ia berpendapat sesuai dengan hasil penelitinya, membuktikan bahwa Ekonomi Islam sama sekali tidak dapat ditemukan dalam tradisi Islam. Sehingga istilah-istilah dan lembaga-lembaga bisnis sekarang yang tidak ada contoh dari Nabi dan tidak pernak ada pada zaman nabi adalah bid'ah. Nak, lalu apakah yang dimaksud dengan bid'ah menurut para ulama dan adakah bid'ahbid'ah dalam ekonomi Islam.

Hasil pembahasan menyatakan, bid'ah adalah setiap perbuatan yang tidak ada dan tidak dilakukan pada zaman Nabi yang bertentagan dengan nash al-Qur'an dan sunnah serta mashlahah. Melihat praktek ekonomi modern, maka banyak bid'ah-bid'ah dalam ekonomi Islam, diantaranya adalah istilah ekonomi Islam itu sendiri. Kegiatan dari ekonomi Islam di Indonesia yang merupakan bid'ah adalah perbankan syariah, zakat propesi dan lainya. Secara etimologi ketiga disebut dengan bid'ah, namun secara terminology belum dapat dikatakan bid'ah. Sedangkan kaidah fiqih menjelasan "al-ashlu fil mu'amalah ibahah, illa ma dalla dalilun 'ala tahrimihi", maksudnya hukum asal perbuatan dalam muamalah adalah boleh, kecuali ada dalil yang mengharamkannya. 
Kaedah inilah yang menutup pemaknaan kototasi buruk dari ungkapan bid'ah, menjadi bid'ah hasanah (baik) karena mengandung banyak kemashlahatan untuk manusia.

\section{DAFTAR PUSTAKA}

Abd al-Ra'uf Muhammad al-Munawi, Faidh al-Qadir Syarah Jamius Shagir, (Beirut: Darul Ma'rifah, 1982), juz VI, hadits 8333

Abdul Illah bin Husain al-arfaj, Mafhum Bid'ah (Riyad: Darul fatah, 2012 $\mathrm{M} / 1433 \mathrm{H}$ ), cet. II, dan terjemhan: Mohammad Taufiq Q Hulaimi, Konsef Bid'ah dan Toleransi Fiqih (Jakarta: I'tishom, 2013), cet. II

Abdul Illah bin Husain al-Arfaj, Mafhumul Bid'ah (Riyad: Darul fatah, $2012 \mathrm{M} / 1433 \mathrm{H})$ dan tejemahan Mohammad Taufiq Q Hulaimi, Konsef Bid'ah dan Toleransi Fiqih (Jakarta: I'tishom, 2013), cet. II

Abdul Manan, Hukum Ekonomi Syariah, (Jakarta: Kharisma Putra Utama, 2012), hlm. 203

Abdullah Saeed, Islamic Banking And Interest: A Study of The Prohibilition of Riba And Its Contemporary Interpretation, $\mathrm{Ej}$ Brill, Leiden, 1996

Abdur Rahman bin Abu Bakar bin Muhammad bin Sabiq AlKhudhari As-Suyuthi, Syarah Assuyuthiy, (Beirut: Darul Ma’arif, 1138 H), Juz III

Abdurrahman bin Syihabuddin Zainuddin Abul Faraz ibnu Rajab alHambali, Jami al-'Ulum wal-
Hikam, (Darul Ibnu Katsir, 2008 M/1429 H), juz II

Abi Abdillah Muhammad bin Ahmad alAnshari al-Qurthubi, Jamiul Ahkamil Qura'an, Tafsir al-Imam al-Qurthubi, (Mesir: daru Kutub, $1935 \mathrm{H})$, jilid II

Abi Abdillah Muhammad bin Muhammad bin Muhammad Abdari alMashury bi Ibnul-Hajj, "Madkhal asy-Syar'asy-Syarif, (Mesir: Iskanadariyah, $1291 \mathrm{H}$ ), jilid II

Abil Qasyim ali bin Hasan bin Habbatatllah Ibn 'Asakir ad-Dimiqi, Tabyin Kadzib al-Muftari, ( Dimsqa Syam: Maktabatah at-Tausin, 1347)

Abu Abdillah bin shalih bin Muhammad bin Sulaiman bin Abdurrahman alUtsaimin al-Wuhaiby at-tamimy, Al-Majmu' al-Tsamin, (Riyad: Darul Wthan, 1413 H), juz I

Abu Abdillah Muhammad bin Ahmad bin Utsman bin Qaimaz bin Abdullah adz-Dzahabi al-Fariqi dalam "Siyar", jilid VIII

Abu Bakar al-Mulla al-Hanafi, Mahdun nashihah li muridi al-aqidah ashShahihah (Beirut: Darul Fikri, 1999 M/1420 H)

Abu Fdhli Ahmad bin Ali bin Muhammad bin Ahmah bin Hajar Al-Asqolani, Fathul Brri, (Bairut: Darul Ma'arif, 2003), jilid IV.

Abu Hamid Muhammad bin Muhammad bin Muhammad Imam Gazali atThusi, Ihya Ulumuddin, (Mesir: Darul Fikri, 2007), jilid I

Abu Ishak Ibrahim bin Musa Al-Syathibi, Al-I'tisham, (Beirut: Maktabah Tauhid, 790 H), Juz. I dan 
Jurnal Ilmiah Ekonomi dan Bisnis

Vol. 15. No. 2, September 2018: 122-138

EISSN : $2442-9813$

ISSN : $1829-9822$

Ringkasan: Alwi bin Abdul Qadir as-Seqqaf, Mukhtasar Kitabu I'thisam, (Darul Hijrah, 1997) dan Terjemahan: Arif Syarifuddin, Lc, Membedak Seluk Beluk, (Yokyakarta: Media Hidayah, 2003)

Abu Muhamad Izzuddin 'Abdul 'Aziz bin 'Abdul Salam al-Sulami alSyafi'i, Qawa'id Al-Ahkam fi Mashalih Al-Anam, (Bairut: Darul Ma'arif, 2001), jilid II

Agus Marimin dan Tira Nur Fitria, Zakat Profesi (Zakat Penghasilan) Menurut Hukum Islam (Jurnal Ilmiah Ekonomi Islam - Vol. 01, No. 01, Maret 20150

Ahmad bin Ali bin Muhammad bin Muhammad bin Ali bin Mahmud bin Ahmad bin Hajar Al-Kannani Al-Asqalani Al-Mishri, Fath alBari bi Syarah Shahih Bukhari, (Mesir: Darul al-Hadist, 1985), juz XIII

Ahmad bin Muhammad Ash-Shawiy alMaliki, Tafsir al-Shawy, (Jakarta: Darul Ihya al-Kutub al-Arabiyah, tt), Juz. IV

Ahmad bin Muhammad Ash-Shawiy alMaliki, Tafsir al-Shawy, (Jakarta: Darul Ihya al-Kutub al-Arabiyah, tt), Juz. IV

Ahmad bin Syu'aib Al Khurasany atau Imam An-Nasa i, Shahih Sunan Nasa'i, tahqiq: Muhammad Nashiruddin Al-Bani, (Jakarta: Putaka Azzam, 2013), jilid I

Ahmad El-Najjar, Bank Bila Fawaid Ka Istiratijiyah Lil Tanmiyah AlIqtishadiyah, King Abdul Aziz University Press, Jeddah, 1972
Ali as-Salus, Mausu'ah al-Qadhaya alFiqhiyah al-Mu'ashirah, (Cairo: Maktabah Ilmiyah, 1427 H)

Al-Imam Abu Umar Yusuf bin Abdil barr al-Namiri al-Andalusi, $\quad A l$ Istidzkar, (Beirut: Dar kuttaibah, 1993), jili V

Al-Imam Abul Husain Muslim bin al-Hajjaj al-Qusyairi an-Naisaburi, Shahih Muslim, no.1017

Al-Yazid Ar-Radhi, Zakah Rawatib AlMuwazhaffin, (Lebanon: Maktabah Alamiyah, $1423 \mathrm{H}$ )

AmalMadinah,KepalsuanEkonomilslam.wi besiteonline.https://sunnahmadinah .wordpress.com/2016/01/05/kepals uan-ekonomi-islam2/.diakses25Februari2018.

Ardiansyah, Zakat Propesi Sucikan Hati Bersihkan Penghasilan (Kumpulan Makalah Muzakarah MUI-SU),

Arif Mufraini, Akuntansi dan Manajemen Zakat (Jakarta: Kencana, 2006)

As-Subki, Ad-Durar Al-Kamin, jilid I

Badaruddin Abi Muhammad Mahmud bin Ahmad al-Yani, Umdat Al-Qari Syarah Sahih Bhuhari, (Bairut: Maktabah Darul Kutub al-Ilmiyah, $855 \mathrm{H}$ ), juz XI, hlm: 126 dan juz XVII, hlm: 155.

Deni Setiawan, Zakat Propse dalam pandangan Islam (Jurnal Maret 2011)

Departemen AgamaRI, al-Qur'an dan Terjemhanya, Qs. Al-hadid (57) ayat 27 
Didin Hafidhuddin, Panduan Praktis

Tentang Zakat, Infaq, Sedekah, (Jakarta: Gema Insani Press, 2008)

Pailis, E. A., Burhan, U., \& Ashar, K. (2016). The Influence of Maqashid syariah toward Mustahik's Empowerment and Welfare (Study of Productive Zakat Recipients on Baznas Riau). American Journal of Economics, 6(2), 96-106.

Fahruddin ar-Razi Muhammad bin Umar bin Husein, Manaqib As-Syafii' (Mesir, Maktabah Kulliyah alAzhar, 1986M/1406 H), jilid I

Hamid al-Din Abu'l-Hasan Ahmad bin 'Abdallah al-Kirmani, alKawakib ad-Darari Syarh Shahihal-Bukhari, (Mesir: Darul Kutub, 1937), jilid IX

Ibn Rusyd. Bidâyat al-Mujtaahid, juz I, (t.t. Mustafa babi halabi, 1379 H$1960 \mathrm{M})$

Waldelmi, I., \& Aquino, A. (2018). Analisis Penerapan Transaksi Jual Beli Syariah di Pasar Syariah. Jurnal Inovasi Bisnis (Inovbiz), 6(1), 1-7.

Idris bin Baidiki at-Turkmani, al-Luma fil-Hawadits wal-Bida', (Darul Ihyail Kutubil al-Arabiyati, 1406 H), jilid I

Imam Abi Bakri Muhammad bin Walid At-Turtushi, al-Hawadits walBida, (Riyad: Drul Ibnu Jauzi, 1990)

Imam Abu Zakariya Muhyiddin bin Syarifuddin ibnu Syarif AnNawawi, Tahdzibul 'Asma wal
Lughot, (Darul Kutub Ilmiyah, tt), jilid III

Imam Al-Hafizh Al-Muttaqin Abu Bakar Ahmad bin Al-Husain bin Ali bin Musa Al-Khusrauijrdi AlKhurasani Al-Baihaqi, Manaqib Asy Syafii, (Mesir: Darul asSunnah, 1997), juz I

Imam Al-Mufassir Al-Allamah Al-Qurtubi dan Imam Al-Mufassir Ibn Kathir (Tabaqat As-Syafi'iyyah Al-Kubra, jilid X

Imam Humaid al Himyari, "al-Bid'ah alHasanah, (Bairut: Darul Ilmiyah, 1999)

Kautsar Riza Salman, Akuntansi Perbankan Syariah, (Akademia Pertama, Padang, 2001)

Majallah, Majalah al-Da'wah, terbitan tgl 7 bulan11 (Nopember) tahun $1410 \mathrm{H}$

Mardan, J. A. (2015). Optimalisasi Kinerja Amil Melalui Budaya, Kreativitas, Sarana Prasarana dan Kepercayaan Pada Lembaga Amil Zakat (LAZ) di Kota Pekanbaru. Jurnal Daya Saing, 1(1), 79-90.

Mubarak bin Muhammad Jazri bin Atsir Majduddin Abu as-Sa'adah, Nihayah Fi Gharib Hadits wal atsar, (Beirut: Dar Ibnu Jauziyah, $1423 \mathrm{H})$, juz I

Muhamad bin Abdullah bin Muhamad Abdullah bin Ahmad bin al-Arabi al-Isbili al-Maliki, Aridhat AlAhwadzi Syarah Jami' Attirmidziy, (Bairut: Darul Kutub al-Ilmiyah, tt), jilid X

MuhammaAli Adz-Zdabi'i, penterjemah: Drs. Muhammad Thalib, Bahaya Mengekor Non Muslim, 
Jurnal Ilmiah Ekonomi dan Bísnis

Vol. 15. No. 2, September 2018: 122-138

EISSN : $2442-9813$

ISSN : 1829-9822

(Yokyakarta: Media Hidayah, 2003)

Muhammad ali bin syekh bin Qadhi Muhammad Hamid ibni Muhammad shabiri al-Faruqi atTahanawi al-Hindi al-Hanafi, Kassyaf Istilahatal-Funun, (AlHindi: Musiti afi bankal Kulkulah, 1652 M), jilid I

Muhammad Amin bin Umar Ibnu Abidin, Darul Mukhtar alad Daril Mukhtar al-Hasyiyah Ibnu 'Abidin, (Darul Ilmi al-kutubi, 2003), jilid I

Muhammad Hamrozi, Implementasi Zakat Propesi di Universitas Muhammadiyah Malang (Skripsi 2007)

Muhammad, Zakat Propesi, Wacana Pemikiran dalam Fiqih Kontemporer (Jakarta: Salemba Diniyah, 2012)

Nurhadi, Analisis Hukum Perikatan Klausul Akad Pembiayaan Murabahah Bil Wakalah Nomor.090/MRBH/PKB/V/2016

Bank Rakyat Indonesia Syari'ah (Tesis UIR, 2016)

Nurhadi, Kaifiat Shalat yang di Bid'ahkan Perspektif Empat Mazhab (Bid'ah muttafaqah dan Mukhtalafah) (Tesis UIN Suska Riau, 2014)

Said Muhammad az-Zurqani, "Syarh alMuwattha', (Mesir: Iskandariyah, $1280 \mathrm{H})$, jilid I

Sayyid Al-Bakri Abu Bakar bin Muhammad Syatha' Addimyatiy, I'anah At-Thalibin, (Semarang: Toha Putra, tt), juz II
Shihabuddin Ahmad bin Idris ibni Abdi Rahman as-Shanhaji as_syahiri alQarafi, al-Furuq, (Darul Kutub alIlmiyah, 2001), jilid IV

Syaikh Abdul Lathif al-Sha'idi, Al-I'tidal Fima Sya'a 'An al-Bid'ah Min alAqwal, (Mesir: Darul Fikri, 2006)

Syihabuddin Ahmad bin Hajar Al-Haitami, Fathul Mubin, Al-'Amirah As Syarfiah, (Mesir: Darul Fikri, 2003)

Taqiyuddin Ibnu Taimiyah, I'tiqad Siratal Mustaqim, (Lebanon: Darul Fikr Lebanon, $1421 \mathrm{H}$ ),

Tutik Hamidah, M.Ag (dosen Fakultas Syariah UIN Maliki). Sumber : http://www.elzawauinmaliki.org/zakat-profesimenurut-fatwa-ulamakontemporer/.diakses24Februari20 18.

Wahbah az-Zuhaili, al-Fiqh al-Islami wa Adillatuhu, (Cairo: Maktabah Ilmiyah, 1429 H), juz II

Yusuf Al-Qaradhawi, Fiqh az-Zakah, (Mesir: Maktbah Ilmiyah, 1427H), juz I

Yusuf Qardawi, Hukum Zakat (Bogor: Litera Antar Nusa, 2007)

Wahbah Juahaili, Ushul Fiqhi al-Islami, Juz I

Zainuddin abil Faraj Abdirrahman bin Syihabuddin al-Bagdadi as-Syahiri ibni Rajab al-Hambali, Jamiul Ulumi wal Hikam, (Beirut Mesiar: Darul Ibnu Katsir, 2008) 